\title{
PENTINGNYA MENINGKATKAN PROSES PENGKAJIAN DALAM PELAYANAN ASUHAN KEPERAWATAN
}

\section{Miranda Sipayung}

\author{
Miranda.sipayung068@gmail.com
}

\section{Latar Belakang}

Pengkajian merupakan tahap awal dari proses keperawatan. Pada tahap ini semua data dikumpulkan secara sistematis guna menentukan kesehatan pasien. Pengkajian harus dilakukan secara komprehensif terkait aspek biologis, psikologis, sosial maupun spritual klien. Tujuan pengkajian adalah untuk mengumpulkan informasi dan membuat data dasar klien. Ada empat metode pengumpulan data yang dapat digunakan oleh seorang perawat yaitu wawancara, observasi sistematis, konsultasi, dan pengkajian fisik. Selama proses pengkajian, ada dua jenis data yang harus dikaji seorang perawat, yaitu data subjektif dan data objektif. Data subjekt if adalah data yang didapat berdasarkan persepsi klien tentang masalah kesehatannya. Sedangkan data objektif adalah data yang didapat

Dengan melakukan pengkajian perawat dapat mengidentifikasikan status kesehatan saat ini. Serta pengkajian adalah langkah pertama yang paling penting untuk membuat rencana perawatan individu secara tepat. Didalam proses keperawatan, pengkajian menjadi poin pertama yang harus dilakukan. Itulah sebabnya pengkajian sangat penting untuk dilakukan setiap perawat sebelum melakukan langkahlangkah berikutnya. Pengkajian bertujuan untuk menetapkan suatu database tentang respon klien terhadap perhatian pada kesehatan atau penyakit dan kemampuan untuk mengatur kebutuhan perawatan kesehatan. Manfaat melakukan pengkajian yaitu kepuasan bagi perawat, menambah pengetahuan perawat, menentukan diagnosa pasien, dan mengetahui perkembangan pasien.

pengkajian merupakan langkah awal yang digunakan dalam tahapan proses keperawatan melalui kegiatan pengumpulan data/ informasi untuk memperoleh hasil yang akurat guna untuk mencapai diagnosa yang tepat dan mengetahui berbagai permasalahan yang ada. Dalam tahapan pengkajian dilakukan pengumpulan data, klasifikasi data, validasi data, dan identifikasi pola atau divisi. Sebelum melakukan pengkajian perawat harus memiliki 
pengetahuan dan kemampuan untuk mengobservasi secara sistematis kepada pasien. Keperawatan dituntut untuk memiliki suatu kemampuan yang intelektual dan memiliki moral. Perawat harus mampu membina hubungan saling percaya terhadap pasien melalui pendekatan personal yang mengupayakan untuk kenyamanan dan keamanan pasien. Dengan hal tersebut perawat dapat menggali informasi melalui pengkajian yang dilakukan.

\section{Metode}

Metode yang digunakan adalah metode kualitatif dengan cara mengumpulkan sebanyakbanyaknya data untuk dianalisis. Yaitu dengan literature review dengan menganalisis yang berfokus pada pentingnya pengkajian dalam proses keperawatan untuk menggali data pasien secara tepat dan efektif. Adapun tinjaun literature review yang digunakan seperti text book, journal, dan buku referensi.

\section{Hasil}

Mengetahui manfaat dari pengkajian dalam proses keperawatan untuk meneggakan diagnosis. Manfaat dari pengkajian memberikan cara pandang yang baru dan luas kepada perawat untuk bisa melakukan pengkajian dengan baik untuk mendapatkan data/informasi yang benar dari pasien.

Pelayanan keperawatan diberikan karena adanya kelemahan fisik dan mental, keterbatasan pengetahuan serta kurangnya pengertian pasien akan kemampuan melaksanakan kegiatan secara mandiri. Kegiatan itu dilaksanakan dalam usaha mencapai peningkatan kesehatan dengan penekanan pada upaya pelayanan kesehatan yang memungkinkan setiap individu mencapai kemampuan hidup sehat dan produktif.

Kualitas pelayanan kesehatan sebenarnya menunjukkan pada penampilan dari pelayanan kesehatan yang dikenal dengan output yaitu hasil akhir dari kegiatan tindakan dokter, perawat, dan tim kesehatan lain yang bekerjasama dalam memenuhi kebutuhan pasien, sehingga baik atau buruknya output sangat dipengaruhi oleh proses (process), masukan (input) dan lingkungan (environment). Kotler (2000) dalam Tjiptono (2008) menjelaskan bahwa kualitas pelayanan kesehatan harus dimulai dari kebutuhan pasien dan berakhir dengan kepuasan pasien serta persepsi positif terhadap kualitas pelayanan. Kualitas pelayanan dipengaruhi oleh ada tidaknya kritikan dan keluhan dari pasien, lembaga sosial atau swadaya masyarakat bahkan pemerintah sekalipun. 
Kualitas pelayanan dapat diwujudkan jika telah ada dan berakhirnya interaksi antara pasien dan perawat.Pelayanan yang berkualitas adalah pelayanan yang memuaskan setiap pemakai jasa pelayanan kesehatan sesuai dengan tingkat kepuasan rata-rata penduduk, serta menyelenggarakan sesuai dengan kode etik dan standar pelayanan profesi yang telah ditetapkan.

Pelayanan yang menguntungkan dan diberikan dalam konteks pelayanan di rumah sakit berarti memberikan pelayanan kepada pasien dan keluarganya didasarkan pada standar kualitas untuk memenuhi kebutuhan dan keinginan mereka, sehingga dapat memperoleh kepuasan yang akhirnya dapat meningkatkan kepercayaan pasien dan keluarganya terhadap rumah sakit (Muninjaya, 2011).

Pengkajian yang baik dalam keberlangsungan asuhan keperawatan yang dilakukan optimal oleh perawat, akan sangat menguntungkan banyak pihak. Perawat mendapatkan data-data yang akurat untuk melanjutkan ke tahap asuhan keperawatan selanjutnya. Klien juga akan merasakan kesenangan tersendiri jika perawat yang menggali informasi itu ramah dan baik.

\section{Pembahasan}

Keperawatan merupakan suatu bentuk pelayanan profesional bersifat humanistik, menggunakan pendekatan holistik, dilakukan berdasarkan ilmu dan kiat keperawatan, berorientasi kepada kebutuhan objektif klien. Praktek keperawatan mengacu pada standar professional keperawatan dan menggunakan etika keperawatan sebagai tuntutan utama. Perawat dituntut untuk selalu melaksanakan asuhan keperawatan yang benar atau rasional (Nursalam, 2007).

Proses pengkajian merupakan tahap awal dari proses keperawatan yang dilakukan secara sistematis dengan mengumpulkan data individu secara komperhensif terkait aspek biologis, psikologis, sosial, maupun spiritual. Proses keperawatan adalah kerangka berpikir yang digunakan perawat untuk melaksanakan fungsi dan tanggung jawabnya secara mandiri. Tahap pertamadari proses keperawatan adalah pengkajian (Hidayat, 2002). Fase dari pengkajia meliputi: pengumpulan data, analisis data, pengelompokan data dan dokumentasi data (Haryanto, 2008).

Pelayanan kesehatan sangat menentukan mutu pelayanan kesehatan. Keperawatan merupakan suatu profesi yang sangat penting dan menentukan dalam pemberian pelayanan kesehatan. Di rumah sakit keperawatan juga memegang peranan yang sangat strategis, dimana kebanyakan 
tenaga kesehatan adalah para perawat yang memberikan asuhan keperawatan (Wang, Hailey, $\& \mathrm{Yu}, 2011)$.

Pelaksanaan asuhan keperawatan profesional diwujudkan dengan menerapkan model praktek keperawatan profesional (MPKP) disetiap ruangan. Menurut Ratna sitorus (2006 dikutip Nursalam 2007), MPKP adalah suatu sistem (struktur, proses dan nilai-nilai profesional), yang memfasilitasi perawat profesional, mengatur pemberian asuhan keperawatan termasuk lingkungan tempat asuhan keperawatan tersebut. Asuhan keperawatan adalah proses pelaksanaan pencatatan asuhan keperawatan yakni dari pengkajian saat masuk sampai pasien dinyatakan sehat. Diagnosis yang diangkat berdasarkan masalah yang ditemukan, perencanaan keperawatan, tindakan yang dilakukan serta evaluasi dari proses asuhan keperawatan yang diberikan (Nursalam, 2007).

Perilaku adalah semua kegiatan atau aktivitas manusia, baik yang dapat diamati langsung, maupun yang tidak diamati secara langsung, oleh pihak luar. Green (1980) mengemukaan bahwa perilaku dipengaruhi oleh tiga faktor yakni: faktor predisposing (pengetahuan, sikap tradisi, kepercayaan, sistem nilai yang dianut), faktor pemungkin (sarana dan prasarana), faktor penguat (sikap perilaku tokoh masyarakat, petugas, undangundang,aturan) (Notoatmodjo, 2012).

\section{Metode Pengumpulan Data dalam Proses Pengkajian}

Dalam mengumpulkan data pengkajian keperawatan, partisipan melakukannya dengan mengobservasi pasien dan melihat data IGD, wawancara pasien dan keluarga, serta melakukan pemeriksaan fisik pasien. Dari hasil wawancara terdapat empat partisipan yang mengungkapkan bahwa data tentang pasien dapat diketahui dengan mengobservasi pasien dan melihat catatan data observasi pasien dari data IGD. Hal ini sesuai dengan penuturan partisipan.

\section{Faktor Penghambat Pelaksanaan Proses Pengkajian}

Faktor-faktor penghambat pelaksanaan proses pengkajian keperawatan yaitu kurangnya kemampuan perawat mengumpulkan data pengkajian yang komperhensif, enggan mengkaji, beban kerja yang tinggi, dan mengkaji itu memakan waktu. Dua partisispan mengungkapkan bahwa penghambat terlaksananya proses pengkajian keperawatan adalah kurangnya kemampuan perawat. Hal ini sesuai dengan penuturan partisispan.

Faktor pendorong perawat melakukan proses pengkajian keperawatan antara lain: 
Tahap proses keperawatan yang harus dijalankan dan prosedur tetap rumah sakit dalam menerima pasien baru. Melakukan pengkajian adalah proses pertama yang dilakukan sebelum dapat melakukan asuhan keperawatan pada pasien (Alfaro-LeFevre, 1994)

Metode pengumpulan data yang dilakukan perawat berdasarkan hasil wawancara peneliti antara lain mengobservasi pasien secara langsung, melihat catatan dari IGD, mewawancarai pasien dan keluarganya, dan memeriksa fisik pasien dari kepala sampai ujung kaki (Kozier et al., 2004). Dengan pelaksanaan proses pengkajian keperawatan, perawat mendapatkan beberapa manfaat antara lain: perawat merasa puas telah dapat melaksanakan tugasnya (Syaiin, 2008), bertambahnya pengetahuan dan pengalaman perawat (Kozier et al., 2004), diketahuinya masalah yang terjadi pada pasien sehingga dapat ditentukan diagnosanya, serta dapat dievaluasinya asuhan keperawatan yang telah dilakukan (Kozier et al., 2004; Sand-Jecklin et al., 2010).

Pada tahap pengkajian terdapat tiga komponen yang menjadi tahapan dalam proses pengkajian yaitu pengumpulan data, klasifikasi data, validasi data, dan identifikasi pola atau divisi. Dari setiap tahapan dalam pengakajian tersebut memiliki manfaat untuk penegakkan diagnose, karena setiap tahapan memiliki hubungan saling keterkaitan yang akan mempengaruhi hasil pendiagnosaan dan tahapan selanjutnya.

1. Pengumpulan Data adalah suatu cara yang dilakukan untuk mengumpulkan informasi secara sistemik tentang pasien. Pengumpulan data bermanfaat untuk perawat agar mengetahui situasi, kondisi, dan kebutuhan yang harus dipenuhi. Data/ informasi dapat diperoleh dari pasien, keluarga, orang terdekat dan rekam medik. Pasien sendiri menjadi sumber informasi primer, karena pasien yang mengalami dan lebih mengetahui tentang kondisi yang dirasakan. Keluarga, orang terdekat dan rekam medik menjadi sumber informai sekunder. Informasi sekunder berupa catatan Kesehatan pasien, laporan laboratorium dan tes diagnostik. Metode pengumpulan data meliputi observasi, wawancara, pemeriksaan, dan konsultasi. Data yang diperoleh di bagi menjadi dua, yaitu data subjektif dan data objektif. Data subjektif merupakan data yang menunjukan persepsi yang diungkapkan oleh pasien maupun keluarga pasien melalui ucapan. Contoh: "saya merasa sesak napas". Data objektif merupakan data yang didasari oleh kejadian yang dapat diamati, dilihat, diukur, didengar, dan dirasa. Data objektif dari kejadian ini dapat diamati dan dikumpulkan selain dari pasien. Contoh : Re : 40x/mnt. 
2. Klasifikasi Data adalah suatu cara yang dilakukan untuk mengelompokan data sesuai dengan masalah dan cara penyelesaiannya dengan melihat dari kebutuhan yang harus dipenuhi. Kebutuhan yang harus dipenuhi tersebut adalah: kebutuhan fisiologis, rasa aman dan nyaman, rasa cinta memliki \& dimiliki, harga diri dan aktualisasi diri. Klasifikasi data akan membatu perawat untuk menentukan Tindakan keperawatan yang sesuai dengan kebutuhan yang harus dipenuhi dari pasien.

3. Validasi Data adalah suatu cara untuk membandingkan antara data subjektif dan data objektif. Perawat membandingkan hasil dari pengumpulan data objektif apakah memvalidasi data subjektif atau tidak. Validasi data akan mencerminkan nilai dan standar yang normal, mengetahui apakah data objektif mendukung data subjektif serta mengetahui apakah informasi yang dikumpulkan akurat atau tidak. Dengan adanya validasi data perawat dapat menentukan apakah hasil yang diperoleh dari pengumpulan data tersebut normal atau tidak. Dengan validasi data akan diketahui apakah ada kemungkinan tambahan atau pengulangan dalam proses pengkajian. identifikasi pola atau divisi membantu dalam mengatur data yang telah dikumpulkan. Dalam identifikasi pola atau divisi ini perawat mengumpulkan data yang saling berhubungan dalam pola atau divisi mana data harus dikelompokkan.

Pelaksanakan proses keperawatan yang baik juga akan memberikan manfaat untuk pasien. Pasien akan merasakan puas terhadap Tindakan perawatan yang telah diberikan. Adanya rasa kebebasan rasa untuk mengungkapkan perasaan, masalah atau keluhan terhadap kebutuhan diri. Sehingga masalah yang timbul juga akan cepat teratasi. Dengan tahapan pengkajian yang dilakukan secara terbuka akan meningkatkan hubungan saling percaya antara pasien dengan perawat. Dengan hasil pengkajian yang baik dan jelas dari pasien maka akan membantu perawat untuk proses perencanaan permasalahan keperawatan

\section{Penutup}

Pelaksanaan proses pengkajian keperawatan di ruang rawat inap merupakan kegiatan komperhensif perawat yang membutuhkan ilmu dan seni keperawatan yang baik. Proses pengkajian merupakan tahap awal dari proses keperawatan yang dilakukan secara sistematis dengan mengumpulkan data individu secara komperhensif terkait aspek biologis, psikologis, sosial, maupun spiritual. Proses keperawatan adalah kerangka berpikir yang digunakan perawat untuk melaksanakan fungsi dan tanggung jawabnya secara mandiri. Tahap pertamadari proses keperawatan adalah pengkajian (Hidayat, 2002) 


\section{Daftar Pustaka}

Achmadi, L. D., Pondaag, L., \& Babakal, A. (2015). Gambaran Tingkat Pengetahuan Perawat dalam Penerapan Standar Asuhan Keperawatan di Ruangan Rawat Inap Interna RSUD Datoe Bhinangkang. Jurnal Keperawtan. 3 (3), 1-3.

Dermawan. (2013). Pengantar Keperawatan Profesional. Jakarta : Gosyen Publising

Haryanto. (2007). Konsep dasar keperawatan dengan pemetaan konsep (concept mapping). Jakarta: Salemba Medika

Kosim, Y. (2015). Konsep Dasar Keperawatan. Jakarta : Cv. Trans Info Medika.

Kozier, Barbara. (2010). Buku Ajar Fundamental Keperawatan: Konsep Proses, dan Praktik. Edisi

Muttaqin, Arif. (2010). Pengkajian Keperawatan Aplikasi pada Praktik Klinik. Jakarta: Selamba Medika. 7. Jakarta : EGC.

Potter, A.P., \& Perry, G.A. (2010). Fundamental Keperawatan Buku 1 Edisi 7. Jakarta : Salemba Medika

Setiawati, Santun dan Dermawan, A. Citra. (2008). Panduan Praktis Pengkajian Fisik Keperawatan. Jakarta: TIM.

Sumijatun. (2010). Konsep Dasar Menuju Keperawatan Profesional. Jakarta: Trans Info Media. Tarwoto, \& Wartonah. (2010). Kebutuhan Dasar Manusia dan Proses Keperawatan. Jakarta : Salemba Medika.

Simamora, R. H. (2019). Development of Guidelines for Applying appropriate Patient Identification to Achieve Patient Safety Goal

INC2019 12th International Nursing Conference. 2019.10455 - 455 (1 pages) UCI(KEPA) : I410-ECN-0101-2019-512-001224337

Simamora. R. H. (2008) The correlation of ward chief's giving direction and command and the performance of on-duty nurses at Jember dr. Subandi general hospital inpatient wards. jurnal Administrasi dan Kebijakan Kesehatan, (https://fkm.unair.ac.id/jurnal-administr) 